\title{
One-step synthesis and chemical characterization of Pt-C nanowire composites by plasma sputtering
}

\author{
Pascal Brault, ${ }^{[\mathrm{a}]}$ Amaël Caillard, ${ }^{[\mathrm{a}]}$ Stève Baranton, ${ }^{[\mathrm{b}]}$ Matthieu Mougenot, ${ }^{[\mathrm{a}]}$ Stéphane Cuynet,${ }^{[\mathrm{a}]}$ and \\ Christophe Coutanceau, ${ }^{*}[\mathrm{~b}]$
}

Small size of nanoparticles (NPs) is proposed as responsible of their specific properties. ${ }^{[1-3]}$ Nanomaterials have thus found numerous applications in chemistry, electronics, optics, information storage, medical, biotechnology. ${ }^{[4]}$ Numerous processes of heterogeneous catalysis (vehicle exhaust and industrial effluent treatments, petrochemistry, sensors, energy storage and conversion...) used costly and strategic metals from the platinum group. ${ }^{[5]}$ Here, a high surface-to-volume ratio leading to large fraction of accessible atoms is required for increasing the activity of the catalyst. ${ }^{[6-8]}$ There is thus a real interest to obtain the highest catalytic surface area from a low metal weight, as for fuel cells ${ }^{[9]}$ or sensors. On the other hand, carbon nanofibers or carbon nanotubes have been proposed as catalytic support ${ }^{[10-12]}$ in place of carbon powders because of their high electrical conductivity, unique surface structure, large surface area and chemical inertia. ${ }^{[13]}$ Moreover, metal NPs deposited on carbon nanotubes or carbon nanofibers display higher electrocatalytic activity and stability. ${ }^{[14,15]}$ Therefore, numerous multistep syntheses of carbon nanowire arrays were developed, such as template methods ${ }^{[16]}$ and catalytic growths $^{[17]}$.

Here we report a plasma-assisted one-step synthesis of $\mathrm{Pt} / \mathrm{C}$ nanowires (Pt-CNW). Such synthesis method is convenient for controlling the metal spreading on a porous support, its localization in depth and the metal NPs size distribution. ${ }^{[18,19]}$ It is an environmental-friendly process (time, energy and atom savings, no harmful chemicals, organic solvent or precursor). The co-sputtering of platinum and carbon atoms on an E-Tek ${ }^{\circledR}$ carbon porous layer $(\mathrm{CPL})$ is achieved in a magnetron sputtering reactor. Two rectangular targets, one of pure carbon and one of $\mathrm{Pt}_{1} \mathrm{C}_{99}$ (atomic ratio), are simultaneously DC biased at fixed power leading to a thin film growth rate of ca. $4 \mathrm{~nm} \mathrm{~min}{ }^{-1}$. Electrodes loaded at $0.010 \mathrm{mg}$ $\mathrm{cm}^{-2} \mathrm{Pt}$ (Pt-CNW/CPL) with a Pt ratio of ca. 30 at $\%$ in the deposited film are produced. The Pt loading and localization profile inside the $\mathrm{CPL}$ is determined using Rutherford Backscattering Spectroscopy: $90 \%$ of Pt atoms are localized in the first $200 \mathrm{~nm}$ depth of the material.

The general morphology of Pt-CNW/CPL (Figure 1a) resembles that of a cauliflower with platinum clusters forming dense sponge-like film on the surface of carbon grains. The

[a] Dr. P. Brault, Dr A. Caillard, Dr M. Mougenot, Dr S. Cuynet Groupe de Recherches sur l'Energétique des lonisés (GREMI), Université d'Orléans, UMR CNRS 7344

14, rue d'Issoudun, 45067, Orléans cedex 2, France

E-mail:pascal.brault@univ-orleans.fr

[b] Prof. C. Coutanceau, Dr. S. Baranton

Institut de Chimie des Milieux et Matériaux de Poitiers, IC2MP, Université de Poitiers, UMR CNRS 7285

4, rue Michel Brunet, B27, 86022, Poitiers, France

E-mail:christophe.coutanceau@univ-poitiers.fr
TEM image in Figure $1 \mathrm{~b}$ shows that a platinum film (darker zones) is deposited on the top of the CPL surface (light grey zones). Columnar structures emerge in the radial direction of the platinum film with respect to the CPL support. Higher magnification in Figure $1 \mathrm{c}$ reveals a Pt NPs arrangement surrounding carbon nanowires over their whole length. The carbon column enlargement from the bottom (ca. $5 \mathrm{~nm}$ ) to the top (ca. $10 \mathrm{~nm}$ ) is explained in terms of a shadowing effect in magnetron sputtering process. ${ }^{[20]}$ Increasing the magnification allows visualizing the platinum clusters and estimating their size to ca. $1 \mathrm{~nm}$ (Figure 1d).
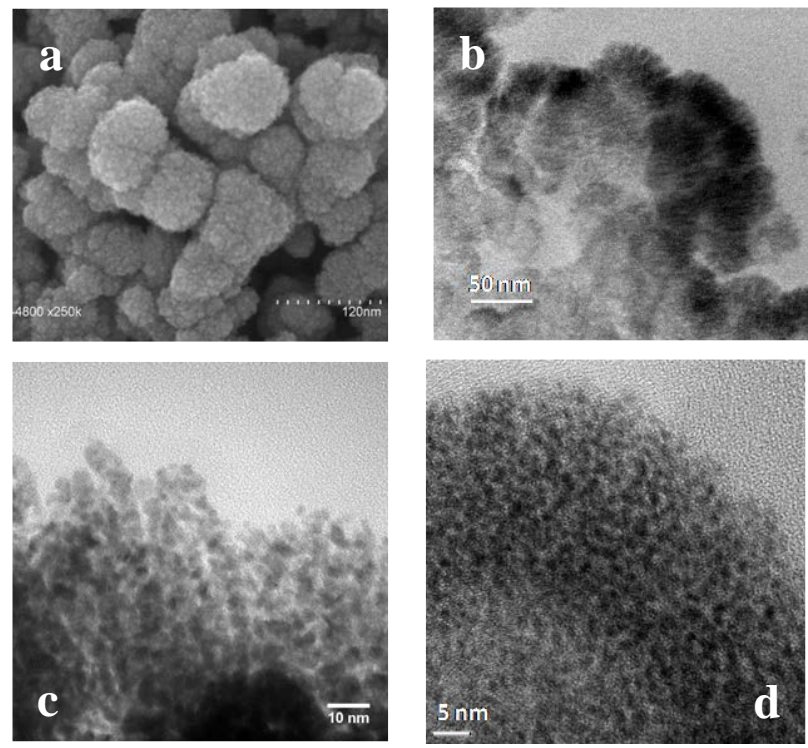

Figure 1. (a) SEM picture of a $0.010 \mathrm{mg} \mathrm{cm}^{-2} \mathrm{Pt}$ on a commercial $\mathrm{CPL}$ (courtesy of D. Cot, IEM); (b-d) TEM images of $0.010 \mathrm{mg}_{\mathrm{pt}} \mathrm{cm}^{-2} \mathrm{Pt}-\mathrm{CNW}$ on a commercial CPL at different magnifications.

ToF SIMS was used to analyze the chemical structure of the material. Due to the complexity of the sample, a lot of mass peaks are recorded and only semi-quantitative analysis can be performed. $\mathrm{CH}_{\mathrm{x}} \mathrm{Pt}$ and $\mathrm{CH}_{\mathrm{x}} \mathrm{OPt}$ are the main molecular ions detected, indicating that strong chemical bonds exist between $\mathrm{Pt}$ atoms and carbon or oxygen atoms, which is a good point for activity and durability issues. ${ }^{[21]}$ ToF SIMS and XPS (Figure 2) measurements show that $P t$ is mainly under oxidized states $\left(\mathrm{PtO}_{\mathrm{x}}, \mathrm{PtO}_{\mathrm{x}} \mathrm{H}_{\mathrm{y}}\right)$. Platinum is only found under $+\mathrm{Il}$ oxidation state by XPS. Plasma synthesis is performed under argon atmosphere, free of $\mathrm{O}_{2}$ and water molecules. Oxygenated species could come from the targets and be sputtered with $\mathrm{Pt}$ and $C$ atoms. The edges of graphene planes are likely ended by hydrogen atoms or oxygenated functions. ${ }^{[22]}$ Because ToF SIMS and XPS measurements were not conducted in situ, the oxidation of the $\mathrm{Pt}$ and $\mathrm{C}$ atoms could also occur as soon as the Pt-CNW/CPL is put in contact with air, forming surface oxides. ${ }^{[23]}$ XPS analysis of 2.5-3.0 nm Pt NPS synthesized by 
colloidal routes ${ }^{[24,25]}$ showed that $\mathrm{Pt}$ atoms on particle surface were + II oxidation state, whereas core $\mathrm{Pt}$ atoms remained under metallic state. ${ }^{[26]}$ For Pt particles co-deposited with carbon by plasma method, all $\mathrm{Pt}$ atoms are found to be oxidized, confirming that the Pt particle size is close to $1 \mathrm{~nm}$. In the case of (hemi)spherical Pt particles, ${ }^{[19]}$ the dispersion D (ratio of surface $N_{s}$ to total $N_{t}$ atom numbers) is inversely proportional to the diameter of the particle $d$ in $\mathrm{nm}^{[27]} ; 5 \mathrm{~nm}$ diameter particle has $20 \%$ surface atoms $\left(\mathrm{N}_{\mathrm{t}} \approx 6000\right.$ atoms), and for $1 \mathrm{~nm}$, one can consider all atoms as surface atoms. The XRD pattern showed no diffraction peak corresponding to Pt fcc structure, only a broad peak at ca. $25^{\circ}$ characteristic of carbon, several peaks assigned to the presence of PTFE in the commercial CPL and a potato-like background, which translates the very low Pt loading and a very amorphous structure. This result is coherent with the very small particle size suggested by TEM and XPS measurements.
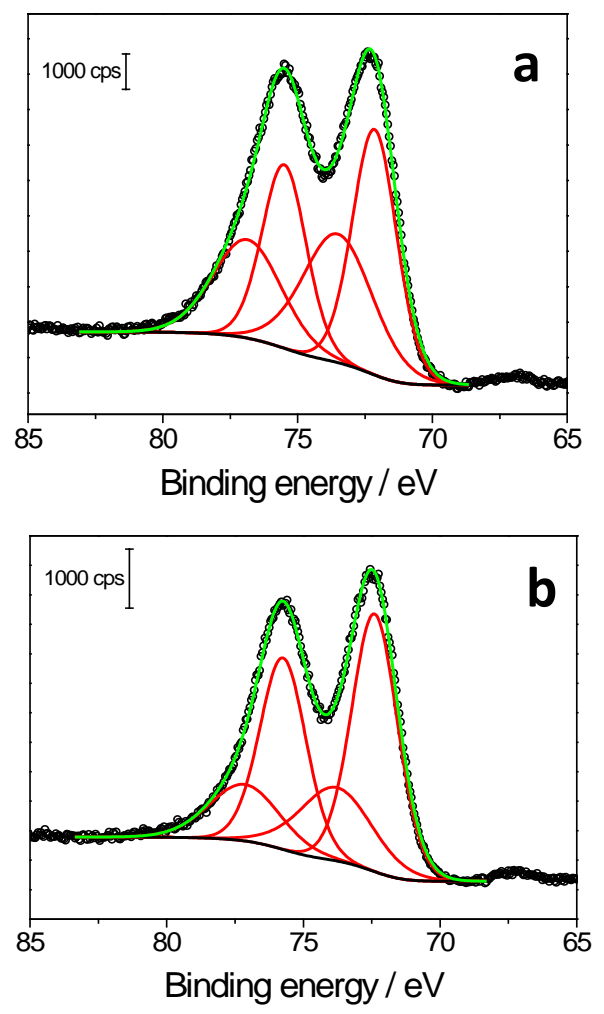

Figure 2. XPS spectra for Pt 4 orbital of $0.010 \mathrm{mg}_{\mathrm{Pt}} \mathrm{cm}^{-2} \mathrm{Pt}-\mathrm{CNW}$ deposited on (a) a Si wafer and (b) a commercial CPL.

Integration of the hydrogen desorption current in the voltammograms (Figure 3 ) gives the electrochemical active surface area (EASA) ${ }^{[28,29]}$. Values ranging from 150 to $200 \mathrm{~m}^{2}$ $\mathrm{g}_{\mathrm{Pt}}{ }^{-1}$ were obtained for Pt-CNW/CPL against ca. $50 \mathrm{~m}^{2} \mathrm{~g}^{-1}$ for a reference $\mathrm{Pt}$ (40wt.\%)/C catalyst made by a colloidal method. ${ }^{[30]}$ Assuming spherical particles of similar radius and whole Pt particle surface utilization, a mean particle size $d$ of ca. $1.3-1.8 \mathrm{~nm}$ is calculated. ${ }^{[26]}$ Values are higher than that estimated from TEM. The contact between Pt NPs in agglomerates and between Pt NPs and carbon can avoid the accessibility to $\mathrm{Pt}$ sites. $\mathrm{C}_{\mathrm{x}} \mathrm{H}_{\mathrm{y}} \mathrm{O}_{\mathrm{z}}$ species formed on the $\mathrm{Pt}$ surface can also be involved. The assumption of spherical particle could also not be valid. After numerical simulation the equilibrium shape of small nanometric clusters could be the icosahedron, ${ }^{[31]}$ which is the most compact shape close to the spherical one, but the equilibrium shape of a supported crystal is the Wulf polyhedron for a free crystal truncated at the interface (here a truncated cuboctahedron).
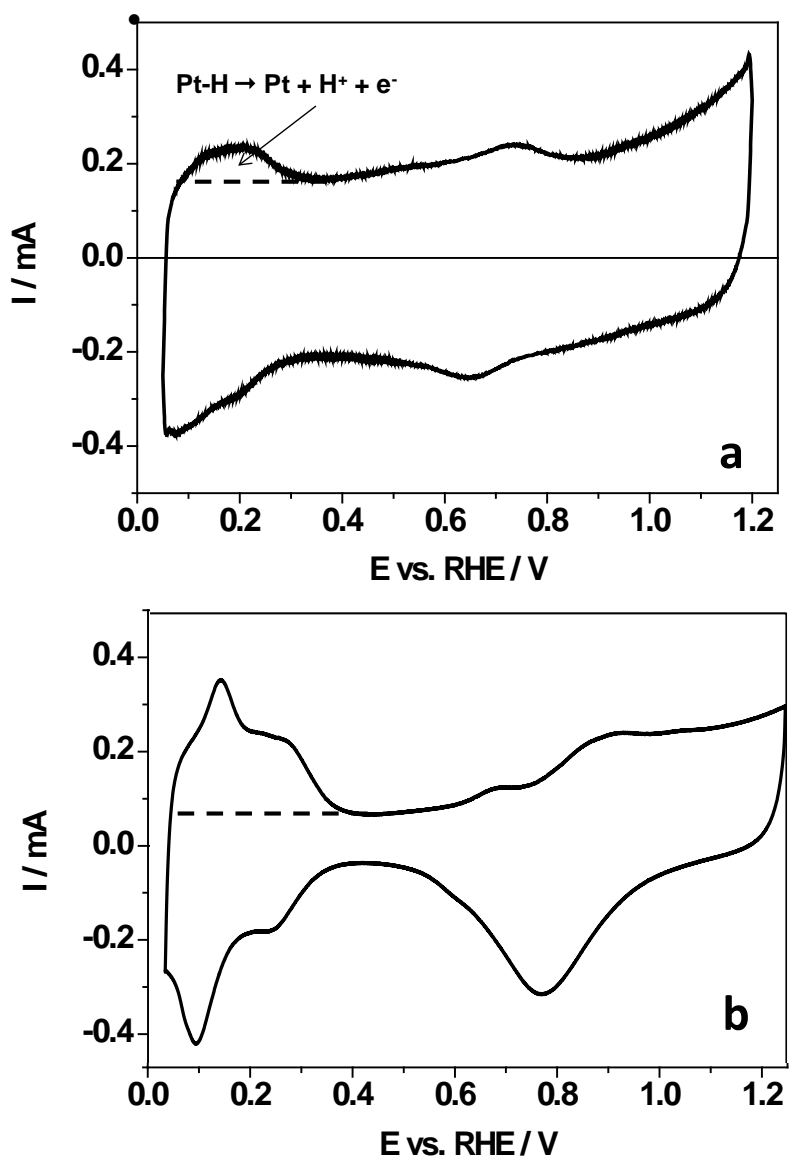

Figure 3. Cyclic voltammograms recorded on (a) $0.010 \mathrm{mg}_{\mathrm{Pt}} \mathrm{cm}^{-2}$ $\mathrm{Pt}-\mathrm{CNW} / \mathrm{CPL}$ electrode and (b) classical Pt/C electrode with $117 \mu \mathrm{g} \mathrm{cm}^{-2}$ of Pt for powders with metal loading of $40 \mathrm{wt}$.\%.(scan rate $=50 \mathrm{mV} \mathrm{s}^{-1}, \mathrm{~N}_{2}$ saturated, $0.05 \mathrm{~mol} \mathrm{dm}^{-3} \mathrm{H}_{2} \mathrm{SO}_{4}, \mathrm{~T}=20^{\circ} \mathrm{C}$ ).

The oxygen reduction reaction (ORR) at the cathode of Proton Exchange Membrane fuel cells is very challenging and is activated by platinum-based catalysts for reaching acceptable kinetics. ${ }^{[32-34]} \mathrm{Pt}-\mathrm{CNW} / \mathrm{CPL}$ materials were then evaluated as cathode catalyst under the harsh fuel cell working conditions. The voltage/power density vs current density curve in figure 4 was obtained with two $0.010 \mathrm{mg}_{\mathrm{Pt}} \mathrm{cm}^{-2} \mathrm{Pt}-\mathrm{CNW} / \mathrm{CPL}$ electrode pressed on a Nafion 212 membrane. At $80^{\circ} \mathrm{C}$, a maximum power density of $0.40 \mathrm{~W} \mathrm{~cm}^{-2}$ is achieved, i.e. $20 \mathrm{~kW}$ $\mathrm{g}_{\mathrm{Pt}}^{-1}$ (highest platinum utilization ever obtained). Fuel cells performances obtained with the reference $\mathrm{Pt}(40 \mathrm{wt} . \%) / \mathrm{C}$ catalyst were previously found higher, with a maximum power density of ca. $1.2 \mathrm{~W} \mathrm{~cm}^{-2}$, but with Pt loading of ca. $0.35 \mathrm{mg}$ $\mathrm{cm}^{-2}$ in electrodes, leading to a Pt utilization rate of only $1.7 \mathrm{~kW}$ $\mathrm{gpt}^{-1} \cdot[30]$ 

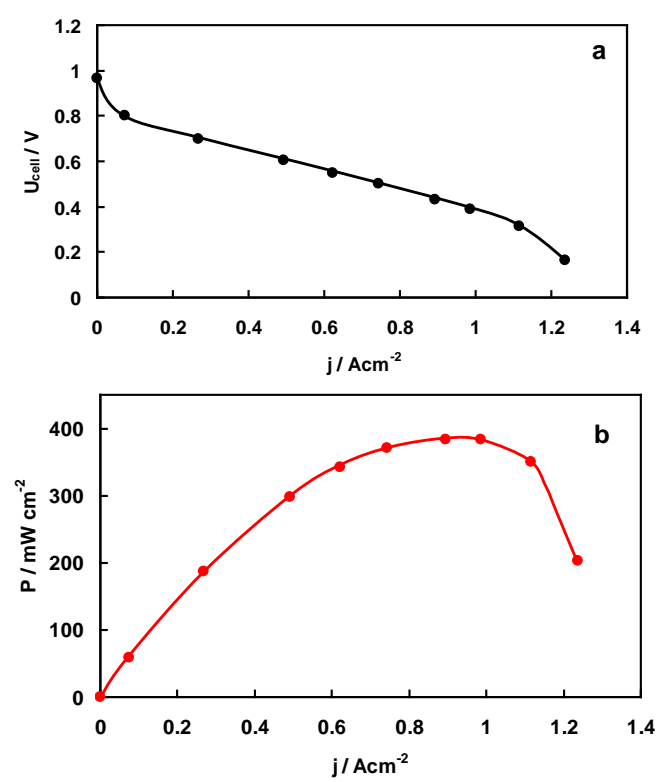

Figure 4. (a) $E(j)$ and (b) $P(j)$ curves obtained at $70^{\circ} \mathrm{C}$ with a MEA of Nafion 212 membrane sandwiched between symmetrical $0.010 \mathrm{mg}_{\mathrm{Pt}} \mathrm{cm}^{-2} \mathrm{Pt}$ CNW/CPL electrodes (Flow rates: $\mathrm{O}_{2}=350 \mathrm{sccm}, \mathrm{H}_{2}=500 \mathrm{sccm} ; \mathrm{T}_{\mathrm{O}_{2}}=40^{\circ}$ $\mathrm{C}, \mathrm{T}_{\mathrm{H}_{2}}=80^{\circ} \mathrm{C}, \mathrm{P}_{\mathrm{O}_{2}}=4$ bars, $\mathrm{P}_{\mathrm{H}_{2}}=3$ bars).

The controlled co-sputtering of platinum and carbon on a porous carbon layer led to a one step formation of carbon nanowires decorated by platinum NPs with diameters from 1 to $2 \mathrm{~nm}$. Strong chemical bonds exist between platinum atoms and carbon or oxygen atoms, and platinum is observed mainly under oxidized states. Very high active surface area and catalytic activity towards ORR were obtained. The film structure, consisting in very small $\mathrm{Pt}$ particles decorating carbon columns with strong interactions, is responsible of the very high metal utilization rate, as exemplified by the electrochemical performances of the material as fuel cell electrodes.

Migration/aggregation of Pt crystallites, Otswald ripening, dissolution of metal and carbon support corrosion are the main degradation processes of $\mathrm{Pt} / \mathrm{C}$ classical electrodes. The strong interaction between the carbon support and the platinum atoms is according to Zhou et al. ${ }^{21}$ a good point for activity and durability issues. According to the Gibbs-Thompson relation the thin film layer structure composed of agglomerated metallic nanoclusters is expected to cause an increase in their chemical potential, and to translate into lower $\mathrm{Pt}$ corrosion kinetics. $^{[35]}$ The relatively dense thin film of $\mathrm{Pt}$ cluster surrounding the carbon nanowires (at the nanoscale level) and the carbon CPL (at a higher scale) is expected to lower metal/carbon/oxygen contact, which could decrease the support corrosion rate. Moreover, the procedure for fuel cell tests imposed the condition that, before fuel cell experiments for several days, the cell had to be conditioned for 2 days at $80{ }^{\circ} \mathrm{C}$ with humidified hydrogen and oxygen fed to the anode and the cathode, respectively. Therefore, because the cell performance was maintained for several days, the nanocomposite structure could be considered to be stable on the FC experimental timescale.

Although the electrode fabrication process is relatively expensive (targets and high vacuum conditions) and fuel cell performances remain too low for automotive applications, where the electric $\mathrm{kW}$ cost has to be low (EU FP7 and US DoE targeted $50 € / \mathrm{kW}$ for electric vehicle), such technology of electrode fabrication is quite applicable for stationary and portable applications. Moreover, physical deposition methods under high vacuum conditions are routinely used in many sectors of industry, especially in metallurgy and microelectronics domains, where the cost reduction is primordial. At last, the very high $\mathrm{Pt}$ utilization makes this material convenient for sensor applications, where the environmental (temperature, pressure, corrosive medium) and electrochemical conditions are smoother.

\section{Experimental Section}

SEM and TEM measurements are carried out with a Hitachi S4800 and a JEOL JEM 2010 (equipped with a LaB6 filament and with a resolution of $0.35 \mathrm{~nm}$ ), respectively.

XPS measurements are performed with an Escalab MKII (VG scientific) set-up using the Magnesium monochromatic beam $(1253.6 \mathrm{eV})$, at room temperature below $810^{-9}$ Torr pressure in the analysis chamber. Core level spectra are recorded with a $50 \mathrm{meV}$ resolution. Binding energies are lined up with respect to the $\mathrm{C}$ 1s peak at $284.6 \mathrm{eV}$.

TOF SIMS measurements are carried out with an IONTOF SIMS IV apparatus on different zones (analyzed surface = $1600 \mu \mathrm{m}^{2}$ ) of a Pt-CNW/CPL to check the homogeneity of the sample.

Electrochemical measurements are performed with a computer controlled Voltalab PGZ 402 potentiostat, at $20^{\circ} \mathrm{C}$ in $\mathrm{N}_{2}$ saturated ( $U$ quality from l'Air Liquide) $1.0 \mathrm{M} \mathrm{NaOH}$ (suprapur from Aldrich) electrolyte. A glassy carbon plate as counter electrode and a reversible hydrogen electrode as reference are used; all potentials are referred to the reversible hydrogen electrode (RHE).

For fuel cell measurements two $5 \mathrm{~cm}^{2}$ surface area $0.010 \mathrm{mg}_{\mathrm{Pt}}$ $\mathrm{cm}^{-2} \mathrm{Pt}-\mathrm{CNW} / \mathrm{CPL}$ electrodes are mechanically pressed on a Nafion 212 membrane (Quintech, Germany) at $2 \mathrm{Nm}$ torque in the cell hardware (Electrochem). Measurements are performed using a ECL150/MTS 150/HSA unit (Electrochem. Inc.).

\section{Acknowledgements}

"Agence Innovation MID" is acknowledged for granting a fellowship (MM). CNRS is acknowledged for granting the PIE "AMEPlas" and ANR is acknowledged for funding the Emergence project "AMADEUS". GdR PACS-CNRS is acknowledged for constant support.

Keywords: Carbon $\bullet$ Composite $\bullet$ Nanostructure $\bullet$ Nanowires $•$ Plasma $\bullet$ Platinum

[1] G.A. Somorjai, Y.G. Borodko, Catal. Lett. 2001, 76, 1-5

[2] K. Kinoshita, in Modern aspects of electrochemistry, Vol. 14 (Eds: C. G. Vayenas, R. E. White, M .E. Gamboa-Aldeco), PLENUM, New York, 1982, pp. 557-637.

[3] K. P. McKenna, in Nanoscale materials in chemistry, (Eds: K. J. Klabunde, R. M. Richards), WILEY, Hoboken, N J, 2009, pp. 15-36.

[4] A. Nel, T. Xia, L. Madler, N. Li, Science 2006, 311, 622-627.

[5] C. Hageluken, Chimica Oggi/Chemistry today 2006, 24, 14-17. 
[6] R. Narayanan, M. A. El-Sayed, J. Am. Chem. Soc. 2004, 126, 71947195.

[7] A. S. K Hashmi, G. J. Hutchings, Angew. Chem., Int. Ed. 2006, 45, 1897-1899.

[8] Y. J. Xiong, B.Wiley, Y. N. Xia, Angew. Chem., Int. Ed. 2007, 46, 7157-7159.

[9] E. J. Yoo, T. Okata, T. Akita, M. Kohyama, J. Nakamura, I. Honma, Nano Lett. 2009, 9, 2255-2259.

[10] B. C. H. Steele, A. Heinzel, Nature 2001, 414, 345-352.

[11] E. Antolini, Appl. Catal. B: Environmental 2009, 88, 1-24.

[12] K. I. Tanaka, M. Shou, Y. Yuan, J. Phys. Chem. C 2010, 114, 1691716923.

[13] P. Serp, E. Castillejos, ChemCatChem 2010, 2, 41-47.

[14] S. L.Candelaria, Y. Shao, W. Zhou, X. Li, J. Xiao, J.-G. Zhang, Y. Wang, J. Liu, J. Li, G. Cao, Nano Energy 2012, 1, 195-220.

[15] A. Caillard, C. Charles, P. Brault, R. Boswell, C. Coutanceau, Appl. Phys. Lett., 2007, 90, 223119 - 1-223119-3.

[16] N. A. Melosh, A. Boukai, F. Diana, B. Gerardot, A. Badolato, P. M. Petroff, J. R. Heath, Science 2003, 300, 112-115

[17] Z. F. Ren, Z. P. Huang, J. W. Xu, J. H. Wang, P. Bush, M. P. Siegal, P. N. Provencio, Science 1998, 282, 1105-1107.

[18] P. Brault, C. Josserand, J.-M. Bauchire, A. Caillard, C. Charles, R. W. Boswell, Phys. Rev. Lett. 2009, 102, 045901-1 - 045901-4.

[19] M. Cavarroc, A. Ennadjaoui, M. Mougenot, P. Brault, R. Escalier, Y. Tessier, J. Durand, S. Roualdès, T. Sauvage, C. Coutanceau, Electrochem. Comm. 2009, 11, 859-861.

[20] M. Mougenot, P. Andreazza, C. Andreazza-Vignolle, R. Escalier, T. Sauvage, O. Lyon, P. Brault, J. Nanopart. Res. 2012, 14, 672.

[21] Y. Zhou, K. Neyerlin, T. S. Olson, S. Pylypenko, J. Bult, H. N. Dihn, T. Gennet, Z. Shao, R. O'Hayre, Energy Environ. Sci. 2010, 3, $1437-$ 1446.
[22] K. Kinoshita, in Carbon: electrochemical and physicochemical properties. J. WILEY AND SONS, New York, 1987, pp. 83-173.

[23] W. Vogel, J. Phys. Chem. C 2008, 112, 13475-13482.

[24] H. Bönneman,W. Brijoux, R. Brinkmann, E. Dinjus, T. Joussen, B. Korall, Angew. Chem. Int. Ed. 1991, 30, 1312-1314.

[25] M. Boutonnet, J. Kizling, P. Stenius, G. Maire, Colloids Surf. 1982, 5, 209-225.

[26] R. Sellin, J-M. Clacens, C. Coutanceau, Carbon 2010, 48, 2244-2254.

[27] C. Henry, in Nanomaterials and nanochemistry, (Eds. C. Bréchignac, P. Houdy, M. Lahmani), SPRINGER, Verlag, 2007, pp. 3-32.

[28] C. Coutanceau, S. Baranton, T. W. Napporn, in The Delivery of Nanoparticles, (Ed. A. Hashim), InTech Publisher, Rijeka, 2011, pp. 403-430.

[29] T. Biegler, D. A. J. Rand, R. Woods, J. Electroanal. Chem. 1971, 29, 269-277.

[30] A.J.-J. Kadjo, P. Brault, A. Caillard, C. Coutanceau, J.-P. Garnier, S. Martemianov, J. Power Sources 2007, 172, 613-622.

[31] C. Mottet, J. Goniakowski, F. Baletto, R. Ferrando, G. Tréglia, Phase transitions 2004, 77, 101-113.

[32] T. R. Ralph, M. P. Hogarth, Platinum Metal Rev. 2002, 46, 3-14.

[33] H. A. Gasteiger, S. S. Kocha, B. Sompalli, F. T. Wagner, Appl. Catal. B: Environmental 2005, 56, 9-35.

[34] V. R .Stamenkovic, B. S. Mun, M. Arenz, K. J. J. Mayrhofer, C. A. Lucas, G. Wang, P. N. Ross, N. M. Markovic, Nature Mater. 2007, 6, 241-247.

[35] J.A.S. Bett, K. Kinoshita, P. Stonehart, J. Catal.1976, 41, 124-133. 
One-step synthesis and chemical characterization of Pt-C nanowire composites by plasma sputtering

\section{COMMUNICATION}

A one-step synthesis of $\mathrm{Pt}-\mathrm{C}$ nanowire composites using a plasma codeposition method is reported. Electrodes with a Pt loading as low as $0.010 \mathrm{mg} \mathrm{cm}^{-2}$ are obtained. Pt particles with sizes from 1 to $2 \mathrm{~nm}$ are decorating with strong interactions columnar carbon nanostructures. The composite microstructure is responsible of the very high metal utilization rate as exemplified from reactions involved in fuel cell electrodes $\left(20{\mathrm{~kW} \mathrm{~g} \mathrm{Pt}^{-1}}^{-1}\right)$.

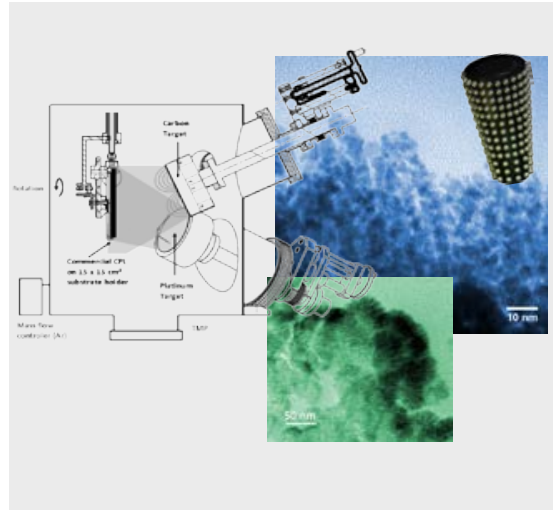

Pascal Brault, Amaël Caillard, Stève Baranton, Matthieu Mougenot, Stéphane Cuynet, and Christophe Coutanceau, *

One-step synthesis and chemical characterization of $\mathrm{Pt} \mathrm{C}$ nanowire composites by plasma sputtering 


\title{
Supporting informations
}

\section{One-step synthesis of Pt-C nanowire composite materials by plasma sputtering}

\author{
C. Coutanceau, P. Brault, A. Caillard, S. Baranton, M. Mougenot, S. Cuynet
}

\section{Plasma co-sputtering method for synthesis}

Pt-CNW are synthesised on a commercial CPL (Elat from E-Tek) in a plasma sputtering apparatus. Figure 1 shows the TEM image of the CPL.

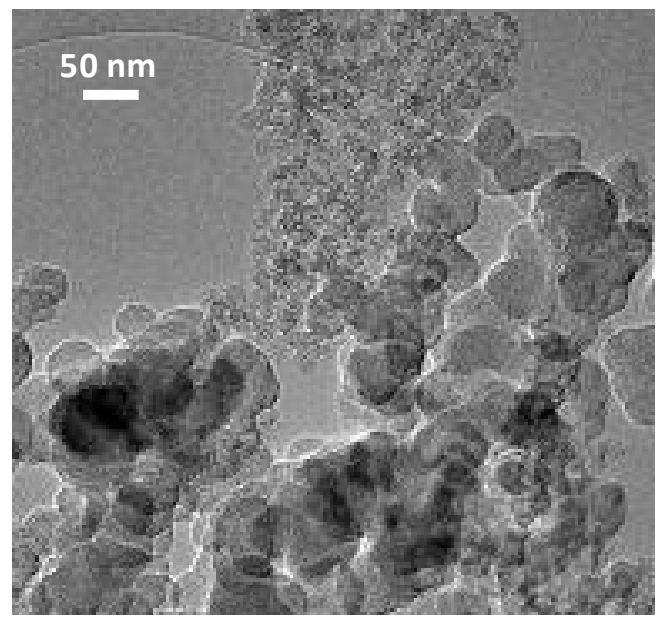

Figure 1: TEM image of the CPL used for Pt-C co-deposition by plasma sputtering

Before deposition process, the $304 \mathrm{~L}$ cylindrical stainless steel chamber is pumped to $510^{-6}$ mbar using a $500 \mathrm{~L} \mathrm{~s}^{-1}$ turbomolecular pump (TV-551 Navigator ${ }^{T M}$ from Varian $^{\circledR}$ ). The CPL is introduced into the deposition chamber through a load lock unit and placed on a $20 \times 20 \mathrm{~cm}^{2}$ substrate holder. The argon pressure is adjusted to $75 \mu \mathrm{bar}$. Two high purity planar targets (one of pure carbon the other of $\mathrm{Pt}_{1} \mathrm{C}_{99}$ atomic ratio) are simultaneously $\mathrm{DC}$ biased at fixed power of $530 \mathrm{~W}$ (target current $0.78 \mathrm{~A}$, target voltage $700 \mathrm{~V}$ ). The targets are placed at a distance of $10 \mathrm{~mm}$ from the substrate holder at an angle of $45^{\circ}$ with respect to the substrate holder axis. The deposition rate of each material, the Pt loadings and the distributions into the commercial CPL were measured using Rutherford Backscattering Spectroscopy (RBS) ${ }^{[1]}$ in the laboratory CEMHTI (Orleans, France). A $2 \mathrm{MeV}$ a particle beam $\left(1 \times 1 \mathrm{~mm}^{2}\right)$ produced in a Van de Graaf accelerator impinges onto the Pt-CNW material. The a particles are backscattered after colliding with a carbon atom or a Pt atom and they are collected by a $25 \mathrm{~mm}^{2} \alpha$ detector (placed at $70 \mathrm{~mm}$ from the sample with a scattering angle of $165^{\circ}$ ). Their energy depends on the mass and on the in-depth position of the collision. The sticking coefficients of Pt and $\mathrm{C}$ atoms on Si were found to be equal to the one on commercial CPL. The deposition time was adjusting to reach a Pt loading of $0.010 \mathrm{mg} \mathrm{cm}^{-2}$ and a ratio of $30 \mathrm{wt} \%$ of $\mathrm{Pt}$ in the deposited film. Figure 2 shows the RBS spectrum of the $0.01 \mathrm{mg}_{\mathrm{Pt}} \mathrm{cm}^{-2}$ loaded CPL. On the right side of the spectrum, the asymmetric peak corresponds to the Pt atoms. The area under this Pt peak is related to the number of Pt atoms inside the Pt-CNW material. The tail on the left side of the Pt peak indicates that the Pt atoms have diffused into the porous CPL. Pt distribution in the depth of the material can be deduced ${ }^{[2]}$. 


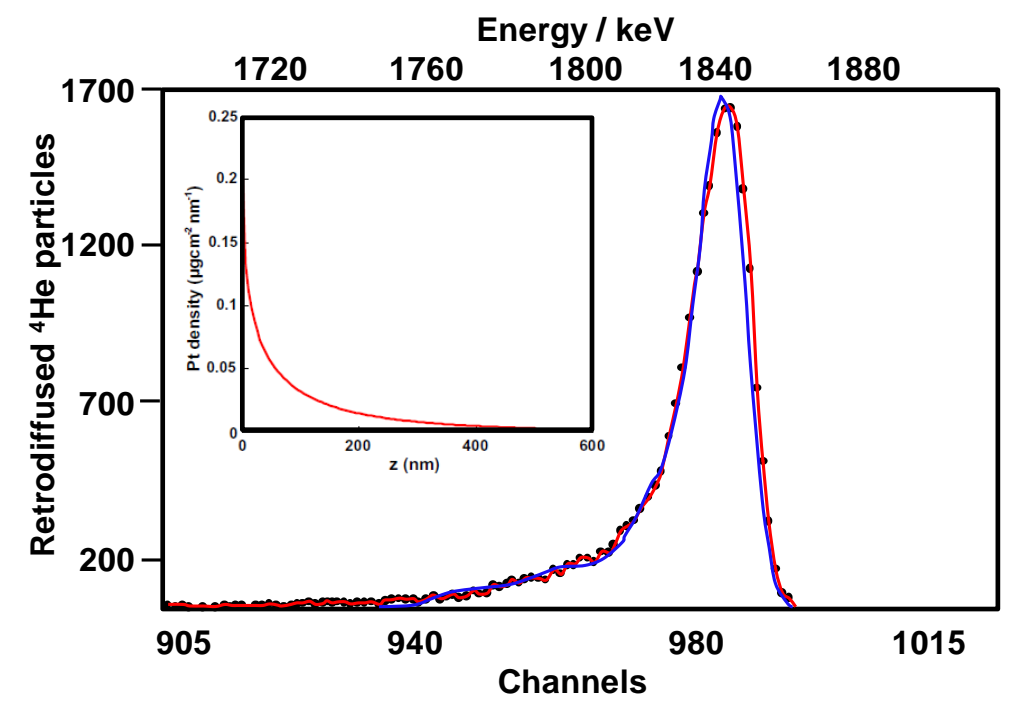

Figure 2: RBS spectrum of Pt from which the platinum density profile (inset) in the composite Pt-CNW/CPL material was determined; experimental data are represented by the red curve, the blue curve is the simulated one to access the density profile.

\section{ToF SIMS analysis}

The ToF SIMS surface analysis technique consists in impinging the surface of a sample with a primary ion beam (in the present case ${ }^{69} \mathrm{Ga}^{+}$) and to analyze the ejected secondary ions. By measuring the ratio masse/charge $(\mathrm{m} / \mathrm{z})$ of secondary ions and their time of flight between the sample and the detector, the elemental composition and the chemical structure of the material upper layers can be determined. The depth resolution is 1-3 monolayers, the atomic resolution is lower than $5 \times 10^{11}$ at $\mathrm{cm}^{-2}$. Three different zones of the samples were measured in order to check the homogeneity of the material. The analysis chamber pressure is set at $510^{-9}$ Torr. The primary ions source of ${ }^{69} \mathrm{Ga}^{+}$is powered at potential of $15 \mathrm{kV}$ leading to $0.67 \mathrm{pA}$ pulsed ionic current (100 ns). The Molecular ions with mass from 1 to 400 containing $\mathrm{C}, \mathrm{O}, \mathrm{H}$ and $\mathrm{Pt}$ were searched in the spectra corresponding to positive and negative polarity of ions (Table 1). Several molecular ions could correspond to the same $\mathrm{m} / \mathrm{z}$ value; however, the DtMass value may help to discriminate the molecular ions: the lower is its absolute value, the closer is the measured mass to the calculated one (the more probable molecular ions are in bold characters). Moreover, due to dependence of the ionic yield of secondary ions on the matrix, the ion intensity is not directly proportional to their concentration; however, while the same matrix is involved for all secondary ions, semiquantitative analysis could be performed, and the main molecular fragments, in terms of amount, could be pointed out.

Molecular peak from ToF SIMS

\begin{tabular}{|c|c|c|c|c|c|c|c|c|c|}
\hline \multirow{2}{*}{$\begin{array}{l}\text { Positive } \\
\text { molecular } \\
\text { ions }\end{array}$} & \multicolumn{3}{|c|}{ Sample 1} & \multicolumn{3}{|c|}{ Sample 2} & \multicolumn{3}{|c|}{ Sample 3} \\
\hline & Ct Mass & $\begin{array}{l}\text { Dt } \\
\text { Mass }\end{array}$ & CI & Ct Mass & $\begin{array}{l}\text { Dt } \\
\text { Mass }\end{array}$ & CI & Ct Mass & $\begin{array}{l}\text { Dt } \\
\text { Mass }\end{array}$ & CI \\
\hline $\mathrm{PtO}$ & 210,9819 & 105,5 & 63,38 & 210,9819 & 100,8 & 70,16 & 210,9819 & 98,1 & 64,96 \\
\hline $\mathrm{CH}_{4} \mathbf{P t}$ & 210,9819 & $-67,1$ & 63,38 & 210,9819 & $-71,8$ & 70,16 & 210,9819 & $-74,4$ & 64,96 \\
\hline PtOH & 211,9839 & 77,2 & 70,64 & 211,9839 & 75,2 & 75,37 & 211,9839 & 77,7 & 75,71 \\
\hline $\mathrm{CH}_{5} \mathrm{Pt}$ & 211,9839 & $-94,6$ & 70,64 & 211,9839 & $-96,5$ & 75,37 & 211,9839 & -94 & 75,71 \\
\hline $\mathrm{PtH}_{2} \mathrm{O}$ & 212,9861 & 50,7 & 48,44 & 212,9861 & 43,3 & 56,55 & 212,9861 & 44,6 & 60,65 \\
\hline $\mathrm{CH}_{6} \mathrm{Pt}$ & 212,9861 & $-120,2$ & 48,44 & 212,9861 & $-127,6$ & 56,55 & 212,9861 & $-126,3$ & 60,65 \\
\hline $\mathrm{PtH}_{4} \mathrm{O}$ & 214,9866 & $-20,4$ & 14,26 & 214,9866 & $-14,8$ & 18,02 & 214,9866 & $-31,4$ & 15,55 \\
\hline $\mathrm{PtO}_{2}$ & 227,0004 & 201,5 & 13,33 & 227,0004 & 203,4 & 14,82 & 227,0004 & 198,8 & 13,68 \\
\hline $\mathrm{CH}_{4} \mathrm{OPt}$ & 227,0004 & 41,2 & 13,33 & 227,0004 & 43 & 14,82 & 227,0004 & 38,4 & 13,68 \\
\hline $\mathrm{PtO}_{2} \mathrm{H}$ & 228,0083 & 201,5 & 29,96 & 228,0083 & 198,9 & 37,81 & 228,0083 & 194,8 & 40,62 \\
\hline $\mathrm{CH}_{5} \mathrm{OPt}$ & 228,0083 & 41,9 & 29,96 & 228,0083 & 39,3 & 37,81 & 228,0083 & 35,1 & 40,62 \\
\hline $\mathrm{PtH}_{2} \mathrm{O}_{2}$ & 229,0104 & 175,3 & 35,95 & 229,0104 & 176,7 & 39,97 & 229,0104 & 176 & 40,7 \\
\hline $\mathrm{CH}_{6} \mathrm{OPt}$ & 229,0104 & 16,8 & 35,95 & 229,0104 & 17,7 & 39,97 & 229,0104 & 17,1 & 40,7 \\
\hline $\mathrm{PtH}_{3} \mathrm{O}_{2}$ & 230,0132 & 152,4 & 23,21 & 230,0132 & 148,9 & 28,67 & 230,0132 & 151 & 27,03 \\
\hline $\mathrm{C}_{3} \mathrm{H}_{2} \mathrm{Pt}$ & 232,9772 & $-13,9$ & 17,98 & 232,9772 & -19 & 19,14 & 232,9772 & $-16,1$ & 15,39 \\
\hline $\mathrm{C}_{3} \mathrm{H}_{3} \mathbf{P t}$ & 233,979 & $-39,8$ & 18,57 & 233,979 & $-37,8$ & 21,15 & 233,979 & $-29,5$ & 23,2 \\
\hline $\mathrm{C}_{2} \mathrm{OPt}$ & 234,9865 & 114,2 & 33,51 & 234,9865 & 115,2 & 33,88 & 234,9865 & 118,5 & 30,77 \\
\hline $\mathrm{C}_{3} \mathrm{H}_{4} \mathrm{Pt}$ & 234,9865 & $-40,7$ & 33,51 & 234,9865 & $-39,8$ & 33,88 & 234,9865 & $-36,4$ & 30,77 \\
\hline $\mathrm{C}_{2} \mathrm{HOPt}$ & 235,9938 & 111,5 & 23,8 & 235,9938 & 99,7 & 28,35 & 235,9938 & 104,7 & 25,97 \\
\hline $\mathrm{C}^{3} \mathrm{H}_{5} \mathrm{Pt}$ & 235,9938 & $-42,8$ & 23,8 & 235,9938 & $-54,5$ & 28,35 & 235,9938 & $-49,5$ & 25,97 \\
\hline $\mathrm{C}_{2} \mathrm{H}_{2} \mathrm{OPt}$ & 236,9905 & 64,3 & 23,88 & 236,9905 & 68,4 & 24,19 & 236,9905 & 68,2 & 24,83 \\
\hline $\mathrm{C}_{3} \mathrm{H}_{6} \mathrm{Pt}$ & 236,9905 & $-89,3$ & 23,88 & 236,9905 & $-85,2$ & 24,19 & 236,9905 & $-85,4$ & 24,83 \\
\hline $\mathrm{CHO}_{2} \mathrm{Pt}$ & 239,9919 & 122,9 & 15,44 & 239,9919 & 105,3 & 17,62 & 239,9919 & 103,5 & 14,82 \\
\hline
\end{tabular}




\begin{tabular}{|c|c|c|c|c|c|c|c|c|c|}
\hline $\mathrm{C}_{2} \mathrm{H}_{5} \mathrm{OPt}$ & 239,9919 & $-28,8$ & 15,44 & 239,9919 & $-46,3$ & 17,62 & 239,9919 & $-48,1$ & 14,82 \\
\hline $\mathbf{C H}_{2} \mathbf{O}_{2} \mathbf{P t}$ & 240,9862 & 66,1 & 12,66 & 240,9862 & 69,8 & 11,21 & 240,9862 & 74,1 & 10,75 \\
\hline $\mathrm{C}_{2} \mathrm{H}_{6} \mathrm{OPt}$ & 240,9862 & $-84,6$ & 12,66 & 240,9862 & $-81,3$ & 11,21 & 240,9862 & $-76,9$ & 10,75 \\
\hline $\mathrm{C}_{3} \mathrm{H}_{3} \mathrm{OPt}$ & 250,0039 & 82,9 & 18,82 & 250,0039 & 76,4 & 20,1 & 250,0039 & 77 & 15,96 \\
\hline $\mathrm{C}_{2} \mathrm{O}_{2} \mathrm{Pt}$ & 251,0009 & 184,4 & 14,35 & 251,0009 & 187,8 & 15,62 & 251,0009 & 178,7 & 15,47 \\
\hline $\mathrm{C}_{3} \mathrm{H}_{4} \mathrm{OPt}$ & 251,0009 & 39,4 & 14,35 & 251,0009 & 42,7 & 15,62 & 251,0009 & 33,7 & 15,47 \\
\hline $\mathrm{CH}_{5} \mathrm{O}_{3} \mathrm{Pt}$ & 259,9946 & 22,7 & 23,13 & 259,9946 & 17,3 & 22,75 & 259,9946 & 17 & 21,9 \\
\hline $\mathbf{C H}_{6} \mathbf{O}_{3} \mathbf{P t}$ & 260,9981 & 6,2 & 27,77 & 260,9981 & 1,6 & 28,03 & 260,9981 & 3,1 & 28,33 \\
\hline $\mathrm{C}_{3} \mathrm{O}_{2} \mathrm{Pt}$ & 263,0022 & 181,1 & 17,89 & 263,0022 & 172,6 & 21,47 & 263,0022 & 171 & 21,41 \\
\hline $\mathrm{C}_{3} \mathrm{HO}_{2} \mathrm{Pt}$ & 264,006 & 165,3 & 12,41 & 264,006 & 165 & 12,9 & 264,006 & 154,4 & 12,37 \\
\hline $\mathrm{C}_{2} \mathrm{H}_{4} \mathrm{O}_{3} \mathrm{Pt}$ & 270,9894 & 31,4 & 13,33 & 270,9894 & 38,6 & 15,86 & 270,9894 & 38 & 13,76 \\
\hline $\mathrm{C}_{2} \mathrm{H}_{5} \mathrm{O}_{3} \mathrm{Pt}$ & 271,9958 & 26,2 & 23,21 & 271,9958 & 17,7 & 23,47 & 271,9958 & 23,2 & 23,04 \\
\hline $\mathrm{C}_{2} \mathrm{H}_{6} \mathbf{O}_{3} \mathrm{Pt}$ & 273,0012 & 17,2 & 23,46 & 273,0012 & 13,2 & 26,19 & 273,0012 & 9,1 & 24,67 \\
\hline $\mathrm{C}_{2} \mathrm{H}_{7} \mathbf{O}_{3} \mathrm{Pt}$ & 274,0088 & 16,3 & 16,12 & 274,0088 & 0,1 & 19,94 & 274,0088 & 6,1 & 18,89 \\
\hline $\mathrm{C}_{3} \mathrm{H}_{5} \mathrm{O}_{3} \mathrm{Pt}$ & 283,9921 & 12 & 15,44 & 283,9921 & 15,7 & 14,34 & 283,9921 & 12 & 14,82 \\
\hline $\mathrm{C}_{3} \mathrm{H}_{6} \mathbf{O}_{3} \mathrm{Pt}$ & 285,0017 & 18,2 & 16,04 & 285,0017 & 23,1 & 15,38 & 285,0017 & 16,7 & 16,28 \\
\hline $\mathbf{C}_{3} \mathbf{H}_{7} \mathbf{O}_{3} \mathbf{P t}$ & 286,006 & 5,9 & 13,17 & 286,006 & 17,3 & 15,62 & 286,006 & 10,9 & 13,76 \\
\hline
\end{tabular}

\begin{tabular}{|c|c|c|c|c|c|c|c|c|c|}
\hline \multirow[t]{2}{*}{$\begin{array}{l}\text { Negative } \\
\text { molecular } \\
\text { ions }\end{array}$} & \multicolumn{3}{|c|}{ Sample 1} & \multicolumn{3}{|c|}{ Sample 2} & \multicolumn{3}{|c|}{ Sample 3} \\
\hline & Ct Mass & $\begin{array}{l}\mathrm{Dt} \\
\text { Mass }\end{array}$ & CI & Ct Mass & $\begin{array}{l}\mathrm{Dt} \\
\text { Mass }\end{array}$ & CI & Ct Mass & $\begin{array}{l}\text { Dt } \\
\text { Mass }\end{array}$ & $\mathrm{CI}$ \\
\hline${ }^{194} \mathbf{P t}$ & 193,9519 & $-55,6$ & 23,17 & 193,9519 & $-59,3$ & 20,25 & 193,9519 & $-31,2$ & 20,36 \\
\hline Pt & 194,9584 & $-32,6$ & 40,24 & 194,9584 & -37 & 41,63 & 194,9584 & $-11,8$ & 35,48 \\
\hline${ }^{196} \mathbf{P t}$ & 195,9613 & $-57,5$ & 44,03 & 195,9613 & $-58,5$ & 44,08 & 195,9613 & $-43,6$ & 33,95 \\
\hline $\mathbf{P t H}_{2}$ & 196,9708 & $-48,8$ & 27,63 & 196,9708 & $-49,6$ & 27,56 & 196,9708 & $-48,5$ & 15,45 \\
\hline${ }^{197} \mathrm{Pt}$ & 197,974 & $-72,3$ & 15,64 & 197,974 & $-72,3$ & 15,75 & 197,974 & $-87,8$ & 8,16 \\
\hline $\mathrm{CH}_{3} \mathrm{Pt}$ & 209,963 & $-120,2$ & 13,73 & 209,963 & $-121,3$ & 15,75 & 209,963 & $-122,7$ & 10,28 \\
\hline $\mathrm{CH}_{4} \mathrm{Pt}$ & 210,9575 & -183 & 17,59 & 210,9575 & $-179,4$ & 16,88 & 210,9575 & $-159,2$ & 12 \\
\hline $\mathrm{CH}_{5} \mathrm{Pt}$ & 211,9627 & $-194,4$ & 20,1 & 211,9627 & $-196,9$ & 21,82 & 211,9627 & -194 & 12,93 \\
\hline $\mathrm{C}_{2} \mathrm{Pt}$ & 218,9599 & $-22,3$ & 19,66 & 218,9599 & $-17,8$ & 19,77 & 218,9599 & $-1,7$ & 10,88 \\
\hline $\mathrm{C}_{2} \mathrm{HPt}$ & 219,9616 & $-50,3$ & 64,64 & 219,9616 & $-57,8$ & 64,21 & 219,9616 & $-34,2$ & 28,18 \\
\hline $\mathrm{C}_{2} \mathrm{H}_{2} \mathrm{Pt}$ & 220,9654 & -68 & 87,33 & 220,9654 & $-71,7$ & 83,38 & 220,9654 & $-46,5$ & 34,35 \\
\hline $\mathrm{C}_{2} \mathrm{H}_{3} \mathrm{Pt}$ & 221,9666 & $-97,5$ & 73 & 221,9666 & $-103,6$ & 71,68 & 221,9666 & $-79,4$ & 28,78 \\
\hline $\mathrm{C}_{2} \mathrm{H}_{4} \mathrm{Pt}$ & 222,9678 & -127 & 60,11 & 222,9678 & $-131,6$ & 61,6 & 222,9678 & $-127,9$ & 19,1 \\
\hline COPt & 222,9678 & 36,2 & 60,11 & 222,9678 & 31,7 & 61,6 & 222,9678 & 35,3 & 19,1 \\
\hline $\mathrm{C}_{2} \mathrm{H}_{5} \mathrm{Pt}$ & 223,9632 & $-181,8$ & 44,18 & 223,9632 & $-181,2$ & 47,17 & 223,9632 & $-151,3$ & 15,32 \\
\hline CHOPt & 223,9632 & $-19,3$ & 44,18 & 223,9632 & $-18,6$ & 47,17 & 223,9632 & 11,2 & 15,32 \\
\hline $\mathrm{C}_{2} \mathbf{H}_{6} \mathbf{P t}$ & 224,9671 & $-198,5$ & 31,29 & 224,9671 & $-204,9$ & 30,74 & 224,9671 & $-172,3$ & 8,69 \\
\hline $\mathrm{CH}_{2} \mathrm{OPt}$ & 224,9675 & $-34,8$ & 30,65 & 224,9675 & $-41,1$ & 29,98 & 224,9675 & $-10,5$ & 8,69 \\
\hline $\mathrm{CH}_{3} \mathrm{OPt}$ & 225,959 & $-107,2$ & 16,52 & 225,959 & $-106,4$ & 17,32 & 225,959 & $-78,6$ & 6,57 \\
\hline $\mathrm{CH}_{4} \mathrm{OPt}$ & 226,9535 & $-165,4$ & 16,64 & 226,9535 & $-168,2$ & 19,41 & 535 & $-155,3$ & 6,83 \\
\hline $\mathrm{PtO}_{2}$ & 226,9535 & -5 & 16,64 & 226,9535 & $-7,8$ & 19,41 & 226,9535 & 5,1 & 6,83 \\
\hline $\mathrm{PtH}_{3} \mathrm{O}_{2}$ & 229,9371 & $-178,2$ & 20,34 & 229,9371 & $-178,8$ & 18,24 & 229,9371 & $-180,3$ & 11,34 \\
\hline $\mathrm{C}_{3} \mathrm{Pt}$ & 230,9408 & $-104,2$ & 23,88 & 230,9408 & $-112,4$ & 24,91 & 230,9408 & $-101,5$ & 11,67 \\
\hline $\mathrm{PtH}_{4} \mathrm{O}_{2}$ & 230,9408 & $-195,6$ & 23,88 & 230,9408 & $-203,8$ & 24,91 & 230,9408 & $-192,8$ & 11,67 \\
\hline $\mathrm{C}_{3} \mathrm{HPt}$ & 231,9498 & $-98,7$ & 24,36 & 231,9498 & $-110,8$ & 24,91 & 231,9498 & $-86,3$ & 10,48 \\
\hline $\mathrm{C}_{3} \mathrm{H}_{2} \mathrm{Pt}$ & 232,9636 & $-72,6$ & 21,61 & 232,9636 & $-82,9$ & 22,62 & 232,9636 & $-76,3$ & 8,75 \\
\hline $\mathrm{C}_{3} \mathrm{H}_{3} \mathrm{Pt}$ & 233,9668 & -92 & 22,37 & 233,9668 & $-97,7$ & 21,74 & 233,9668 & $-77,8$ & 7,76 \\
\hline $\mathrm{C}_{2} \mathrm{HOPt}$ & 69 & $-2,6$ & 24,76 & 69 & $-6,4$ & 25,03 & 69 & 29,6 & 9,28 \\
\hline $\mathrm{C}_{3} \mathrm{H}_{5} \mathrm{Pt}$ & 235,9669 & $-156,8$ & 24,76 & 235,9669 & $-160,6$ & 25,03 & 235,9669 & $-124,6$ & 9,28 \\
\hline $\mathrm{C}_{2} \mathrm{H}_{2} \mathrm{OPt}$ & 236,9668 & -36 & 28,82 & 236,9668 & $-35,4$ & 33,15 & 236,9668 & -7 & 9,75 \\
\hline $\mathrm{C}_{3} \mathrm{H}_{6} \mathrm{Pt}$ & 236,9668 & $-189,6$ & רo & 236,9668 & -189 & 33,15 & 236,9668 & $-160,7$ & 9,75 \\
\hline $\mathrm{C}_{2} \mathrm{H}_{3} \mathrm{OPt}$ & 237,9685 & $-61,8$ & 27,67 & 237,9685 & $-67,5$ & 30,22 & 237,9685 & $-42,9$ & 7,69 \\
\hline $\mathrm{C}_{3} \mathrm{H}_{7} \mathrm{Pt}$ & 237,9685 & $-214,7$ & 27,67 & 237,9685 & $-220,4$ & 30,22 & 237,9685 & $-195,9$ & 7,69 \\
\hline $\mathrm{CO}_{2} \mathrm{Pt}$ & 238,9625 & 33,1 & 30,41 & 238,9625 & 25,4 & 31,5 & 238,9625 & 55,8 & 7,89 \\
\hline $\mathrm{C}_{2} \mathrm{H}_{4} \mathrm{OPt}$ & 238,9625 & $-119,2$ & & 238,9625 & $-126,9$ & 31,5 & 238,9625 & $-96,6$ & 7,89 \\
\hline $\mathrm{CHO}_{2} \mathrm{Pt}$ & 239,9595 & $-12,1$ & 20,94 & 239,9595 & $-20,1$ & 22,14 & 239,9595 & 20,4 & 6,37 \\
\hline $\mathrm{C}_{2} \mathrm{H}_{5} \mathrm{OPt}$ & 239,9595 & $-163,8$ & 20,94 & 239,9595 & $-171,8$ & 22,14 & 239,9595 & $-131,3$ & 6,37 \\
\hline $\mathrm{CH}_{2} \mathrm{O}_{2} \mathbf{P t}$ & 240,9574 & -53 & 16,76 & & & 15,79 & & $-16,7$ & 5,04 \\
\hline $\mathrm{C}_{2} \mathrm{H}_{6} \mathrm{OPt}$ & 240,9574 & $-204,5$ & & 240,9574 & $-209,5$ & 15,79 & 240,9574 & $-167,7$ & 5,04 \\
\hline $\mathrm{PtO}_{3}$ & 242,9563 & 28 & 16,44 & 242,9563 & 24,3 & 16,39 & 242,9563 & 59,6 & 5, \\
\hline
\end{tabular}




\begin{tabular}{|c|c|c|c|c|c|c|c|c|c|}
\hline $\mathrm{CH}_{4} \mathrm{O}_{2} \mathrm{Pt}$ & 242,9563 & $-121,8$ & 16,44 & 242,9563 & $-125,5$ & 16,39 & 242,9563 & $-90,2$ & 5,97 \\
\hline $\mathrm{PtO}_{3} \mathrm{H}$ & 243,9604 & 12,7 & 15,96 & 243,9604 & $-0,1$ & 16,96 & 243,9604 & 55,3 & 4,64 \\
\hline $\mathrm{CH}_{5} \mathrm{O}_{2} \mathrm{Pt}$ & 243,9604 & $-136,5$ & 15,96 & 243,9604 & $-149,4$ & 16,96 & 243,9604 & $-93,9$ & 4,64 \\
\hline $\mathbf{P t H}_{2} \mathrm{O}_{3}$ & 244,9636 & $-6,6$ & 26,87 & 244,9636 & $-16,5$ & 25,6 & 244,9636 & 1,5 & 7,83 \\
\hline $\mathrm{CH}_{6} \mathrm{O}_{2} \mathrm{Pt}$ & 244,9636 & $-155,2$ & 26,87 & 244,9636 & $-165,1$ & 25,6 & 244,9636 & $-147,1$ & 7,83 \\
\hline $\mathbf{P t H}_{3} \mathrm{O}_{3}$ & 245,9632 & $-39,8$ & 32,6 & 245,9632 & $-41,8$ & 32,35 & 245,9632 & $-18,7$ & 9,42 \\
\hline $\mathrm{C}_{3} \mathrm{OPt}$ & 246,9663 & 26,5 & 37,66 & 246,9663 & 22,4 & 38,86 & 246,9663 & 45,6 & 12 \\
\hline $\mathrm{PtH}_{4} \mathrm{O}_{3}$ & 246,9663 & $-58,9$ & 37,66 & 246,9663 & -63 & 38,86 & 246,9663 & $-39,8$ & 12 \\
\hline $\mathrm{C}_{3} \mathrm{HOPt}$ & 247,9603 & $-29,3$ & 39,69 & 247,9603 & $-25,3$ & 38,25 & 247,9603 & $-3,7$ & 10,08 \\
\hline $\mathrm{C}_{3} \mathrm{H}_{2} \mathrm{OPt}$ & 248,9639 & $-46,3$ & 33,04 & 248,9639 & $-53,4$ & 32,51 & 248,9639 & $-12,6$ & 7,23 \\
\hline $\mathrm{C}_{3} \mathrm{H}_{3} \mathrm{OPt}$ & 249,9621 & $-84,3$ & 19,7 & 249,9621 & $-80,2$ & 19,81 & 249,9621 & $-61,5$ & 5,31 \\
\hline $\mathrm{C}_{2} \mathrm{HO}_{2} \mathrm{Pt}$ & 251,9595 & $-11,8$ & 11,54 & 251,9595 & $-14,5$ & 11,93 & 251,9595 & -2 & 2,85 \\
\hline $\mathrm{C}_{3} \mathrm{H}_{5} \mathrm{OPt}$ & 251,9595 & $-156,2$ & 11,54 & 251,9595 & -159 & 11,93 & 251,9595 & $-146,5$ & 2,85 \\
\hline $\mathbf{C}_{2} \mathbf{H}_{2} \mathbf{O}_{2} \mathbf{P t}$ & 252,9538 & $-65,4$ & 11,86 & 252,9538 & $-59,4$ & 12,13 & 252,9538 & $-37,8$ & 3,12 \\
\hline $\mathrm{C}_{3} \mathrm{H}_{6} \mathrm{OPt}$ & 252,9538 & $-209,3$ & 11,86 & 252,9538 & $-203,3$ & 12,13 & 252,9538 & $-181,7$ & 3,12 \\
\hline $\mathrm{C}_{2} \mathrm{H}_{3} \mathrm{O}_{2} \mathrm{Pt}$ & 253,9492 & $-113,9$ & 13,45 & 253,9492 & -104 & 12,94 & 253,9492 & $-109,8$ & 4,18 \\
\hline $\mathrm{CO}_{3} \mathrm{Pt}$ & 254,9366 & $-50,6$ & 20,82 & 254,9366 & $-48,6$ & 22,5 & 254,9366 & $-21,9$ & 5,84 \\
\hline $\mathrm{C}_{2} \mathrm{H}_{4} \mathrm{O}_{2} \mathrm{Pt}$ & 254,9366 & $-193,4$ & 20,82 & 254,9366 & $-191,4$ & 22,5 & 254,9366 & $-164,7$ & 5,84 \\
\hline $\mathrm{C}_{1} 6 \mathrm{H}_{3} 1 \mathrm{O}_{2}$ & 255,2263 & $-23,7$ & 36,78 & 255,2263 & $-34,6$ & 37,89 & 255,2263 & 10,6 & 10,15 \\
\hline $\mathrm{CHO}_{3} \mathrm{Pt}$ & 255,9389 & $-72,3$ & 26,15 & 255,9389 & $-71,6$ & 23,91 & 255,9389 & $-46,1$ & 8,09 \\
\hline $\mathrm{C}_{2} \mathrm{H}_{6} \mathrm{O}_{2} \mathrm{Pt}$ & 256,9319 & $-271,4$ & 35,39 & 256,9319 & $-278,2$ & 33,79 & 256,9319 & -246 & 9,15 \\
\hline $\mathrm{CH}_{2} \mathrm{O}_{3} \mathbf{P t}$ & 256,9319 & $-129,8$ & 35,39 & 256,9319 & $-136,5$ & 33,79 & 256,9319 & $-104,4$ & 9,15 \\
\hline $\mathrm{C}_{2} \mathrm{H}_{7} \mathrm{O}_{2} \mathrm{Pt}$ & 257,9323 & $-298,8$ & 29,62 & 257,9323 & $-302,6$ & 27,12 & 257,9323 & $-258,7$ & 8,02 \\
\hline $\mathrm{CH}_{3} \mathrm{O}_{3} \mathrm{Pt}$ & 257,9323 & $-157,7$ & 29,62 & 257,9323 & $-161,5$ & 27,12 & 257,9323 & $-117,6$ & 8,02 \\
\hline $\mathrm{CH}_{4} \mathrm{O}_{3} \mathbf{P t}$ & 258,9272 & $-207,2$ & 25,64 & 258,9272 & -209 & 23,71 & 258,9272 & -177 & 7,23 \\
\hline $\mathrm{C}_{3} \mathrm{O}_{2} \mathrm{Pt}$ & 262,9635 & 33,5 & 19,78 & 262,9635 & 29,5 & 17,52 & 262,9635 & 21,9 & 4,97 \\
\hline $\mathrm{C}_{3} \mathrm{HO}_{2} \mathrm{Pt}$ & 263,9576 & $-18,4$ & 17,2 & 263,9576 & -21 & 18,04 & 263,9576 & $-3,8$ & 4,18 \\
\hline $\mathrm{C}_{3} \mathbf{H}_{2} \mathbf{O}_{2} \mathrm{Pt}$ & 264,9558 & $-54,8$ & 16,2 & 264,9558 & $-58,5$ & 16,88 & 264,9558 & -19 & 4,11 \\
\hline $\mathrm{C}_{3} \mathrm{H}_{3} \mathrm{O}_{2} \mathrm{Pt}$ & 265,9479 & $-113,5$ & 13,77 & 265,9479 & $-98,5$ & 14,02 & 265,9479 & $-105,5$ & 3,05 \\
\hline $\mathrm{C}_{3} \mathrm{H}_{4} \mathrm{O}_{2} \mathrm{Pt}$ & 266,9536 & $-121,4$ & 12,7 & 266,9536 & $-113,8$ & 12,09 & 266,9536 & $-69,9$ & 2,79 \\
\hline $\mathrm{C}_{2} \mathrm{O}_{3} \mathrm{Pt}$ & 266,9536 & 15 & 12,7 & 266,9536 & 22,5 & 12,09 & 266,9536 & 66,4 & 2,79 \\
\hline $\mathrm{C}_{3} \mathrm{H}_{5} \mathrm{O}_{2} \mathrm{Pt}$ & 267,9562 & $-140,3$ & 11,58 & 267,9562 & $-145,2$ & 11,29 & 267,9562 & $-123,1$ & 3,38 \\
\hline $\mathrm{C}_{2} \mathrm{HO}_{3} \mathrm{Pt}$ & 267,9562 & $-4,5$ & 11,58 & 267,9562 & $-9,4$ & 11,29 & 267,9562 & 12,7 & 3,38 \\
\hline $\mathrm{C}_{3} \mathrm{H}_{6} \mathrm{O}_{2} \mathrm{Pt}$ & 268,9605 & $-152,7$ & 14,01 & 268,9605 & $-153,1$ & 12,09 & 268,9605 & $-101,7$ & 3,18 \\
\hline $\mathrm{C}_{2} \mathrm{H}_{2} \mathrm{O}_{3} \mathrm{Pt}$ & 268,9605 & $-17,4$ & 14,01 & 268,9605 & $-17,8$ & 12,09 & 268,9605 & 33,6 & 3,18 \\
\hline $\mathrm{C}_{2} \mathrm{H}_{3} \mathrm{O}_{3} \mathrm{Pt}$ & 269,9638 & $-34,1$ & 12,06 & 269,9638 & $-37,9$ & 11,21 & 269,9638 & $-17,2$ & 3,18 \\
\hline $\mathrm{C}_{2} \mathrm{H}_{4} \mathrm{O}_{3} \mathrm{Pt}$ & 270,9621 & $-69,1$ & 12,78 & 270,9621 & $-63,6$ & 12,62 & 270,9621 & -19 & 3,91 \\
\hline
\end{tabular}

Table 1 : Molecular ions with mass from 1 to 400 containing $\mathrm{C}, \mathrm{O}, \mathrm{H}$ and $\mathrm{Pt}$ obtained in the spectra corresponding to positive and negative polarity of ions $($ CtMass $=$ centre of mass; DtMass $=$ mass deviation $; \mathrm{Cl}=$ signal intensity $)$. The more probable molecular ions are given in bold characters .

\section{XPS measurements}

Oxidation states of Pt were evaluated by Xray photoelectron spectroscopy (XPS). The deconvolutions of the XPS spectra are carried out using a Shirley function for the background. The separation between peaks corresponding to Pt4f7/2 and Pt4f5/2 is fixed to 3.35 $\mathrm{eV}$, and the ratio was fixed at $3 / 2.1 \times 1 \mathrm{~cm}$ silicon 100 is used as second substrate for the XPS measurement on $\mathrm{Pt} /(\mathrm{C}$ nanowires $) / \mathrm{Si}$ material. I The peaks corresponding to Pt $4 \mathrm{f} 7 / 2$ are located at binding energies of $72.2 \mathrm{eV}$ (Si wafer) / $72.4 \mathrm{eV}(\mathrm{CPL})$, and $73.5 \mathrm{eV}(\mathrm{Si}$ wafer) / $73.2 \mathrm{eV}(\mathrm{CPL})$, corresponding to metallic $\mathrm{Pt}(\mathrm{OH})_{2}$ and $\mathrm{PtO}$, the $\mathrm{Pt} 4 \mathrm{f} 7 / 2$ peak related to metallic $\mathrm{Pt}^{0}$ species being located at binding energy lower than $72 \mathrm{eV}$.

\section{Electrochemical measurements}

The procedure described by Bönnemann and co-workers ${ }^{[3]}$ was slightly modified and adapted for the preparation of the reference $\mathrm{Pt} / \mathrm{C}$ catalyst material. ${ }^{[4]}$ Syntheses were carried out under atmosphere free of oxygen and water, using non-hydrated $\mathrm{PtCl} 2(99.9 \%$ from Alfa Aesar). The first step consisted in the preparation of a tetraalkyltriethylborohydride reducing agent $\left(\mathrm{NAlk}_{4}\right)^{+}\left(\mathrm{BEt}_{3} \mathrm{H}\right)^{-}$, which also acts as surfactant after $\mathrm{Pt}^{2+}$ reduction, preventing any aggregation of the metallic particles: $\mathrm{PtCl}_{2}+2\left(\mathrm{NAlk}^{+}\right)^{+}\left(\mathrm{BEt}_{3} \mathrm{H}\right)^{-} \rightarrow \mathrm{Pt}\left[\left(\mathrm{NAlk}_{4}\right)^{+} \mathrm{Cl}^{-}\right]_{2}+2 \mathrm{BEt}_{3}+\mathrm{H}_{2}$

The colloidal precursor was then dispersed on a carbon support (Vulcan XC72) and treated at $573 \mathrm{~K}$ for 90 min under air to entirely remove the organic surfactant, as shown by thermo-gravimetric analyses (TGA) [24]. Platinum loadings of 40 wt.\% was expected by adjusting the amount of Vulcan XC72 added to the platinum colloid before heat treatment $(\mathrm{Pt}(40 \mathrm{wt} . \%) / \mathrm{C}$.

The working electrode from the reference Pt/C material was prepared by deposition of a catalytic ink on a $0.071 \mathrm{~cm}^{2}$ gold disc. The catalytic powder was added to a mixture of 25 wt.\% (based on the powder content) Nafion solution (5 wt.\% in aliphatic alcohols from Aldrich) and ultra-pure water (MilliQ, Millipore, 18.2 MX cm). After ultrasonic homogenization of the Pt/Vulcan XC72-Nafion ink, a given volume was deposited from a syringe onto a fresh polished gold substrate yielding a catalytic powder loading of $293 \mu \mathrm{g} \mathrm{cm}$, 
i.e. $117 \mathrm{lg} \mathrm{cm}^{-2}$ of platinum for powders with metal loading of $40 \mathrm{wt} . \%$. The solvent was then evaporated under pure nitrogen flow at room temperature.

The electrochemical active surface area (ASA) of the catalysts is evaluated from the cyclic voltammograms recorded at $20 \mathrm{mV} \mathrm{s}^{-1}$ in support electrolyte $\left(\mathrm{H}_{2} \mathrm{SO}_{4} 0.5 \mathrm{M}\right)$, by integration of the charge involved in the adsorption-desorption region of hydrogen between 0.05 and $0.4 \mathrm{~V}$ after correction of the capacitive contribution of the carbon support ${ }^{[5]}$ and assuming a charge of $210 \mu \mathrm{C} \mathrm{cm}^{-2}$ for the adsorption of a monolayer of atomic hydrogen on a smooth polycrystalline platinum surface, according to the following equation: ${ }^{[6]}$

$$
\mathrm{EASA}=\frac{1 / v \int \mathrm{IdV}}{210 \times 10^{4} \times \mathrm{m}_{\mathrm{Pt}}}
$$

where EASA is the electrochemical active surface area $\left(\mathrm{m}^{2} \mathrm{~g}^{-1}\right), v$ the linear potential scan rate $\left(V \mathrm{~s}^{-1}\right), i$ the current $\left(\mu C s^{-1}\right), V$ the electrode potential $(\mathrm{V})$ and $\mathrm{m}_{\mathrm{Pt}}$ the mass of platinum deposited on the electrode $(\mathrm{g})$.

\section{Fuel Cell measurements}

For Membrane electrode assembly (MEA) fabrication, a membrane (a Nafion 212 membrane, purchased from Quintech, Germany, noted further in the text N212) was sandwiched without pre-humidification between two electrodes (an anode and a cathode of $5 \mathrm{~cm}^{2}$ geometric surface each) used as prepared by plasma sputtering (without Nafion solution addition). The MEA is prepared by simply tightening the membrane and symmetric electrodes between two graphite bipolar plates at a $2 \mathrm{Nm}$ torque. No preliminary hot pressing process of electrodes against the Nafion 212 membrane (used as received from Electrochem. Inc.) was performed. No Nafion solution was added in the electrode catalytic layers before use. Under our testing conditions, the pressure is manually regulated with the output valves and hydrogen and oxygen are humidified by bubbling in water at $80^{\circ} \mathrm{C}$ and $40^{\circ} \mathrm{C}$, respectively Measurements in $5 \mathrm{~cm}^{2}$ PEMFC using pure $\mathrm{H}_{2}$ and $\mathrm{O}_{2}$ gases are performed using a ECL150/MTS 150/HSA unit (Electrochem. Inc.).

\section{References}

[1] M. Mayer, A simulation program for the analysis of NRA, RBS and ERDA, in 045207 Technical reports IPP9/113, Max Planck Institut für PlasmaPhysik, Garching, 1997.

[2] P. Brault, A. Caillard, A. L. Thomann, J. Mathias, C. Charles, R. W. Boswell, S. Escribano, J. Durand, T. Sauvage, J. Phys. D 2004, 37, 3419-3423.

[3] H, Bönnemann, W. Brijoux, R. Brinkmann, E, Dinjus, T. Joussen, B, Korall, Angew Chem Int. Ed. 1991, 30, 1312-1314.

[4] L. Dubau, F. Hahn, C, Coutanceau, J.-M., Léger, C. Lamy C, J. Electroanal. Chem. 2003, 554-555, 407-415.

[5] T. Biegler, D. A. J. Rand, R. Woods, J. Electroanal. Chem. 1971, 29, 269-277.

[6] C. Coutanceau, S. Baranton, T. W. Napporn, in The Delivery of Nanoparticles, A. (Ed.: Hashim), InTech Publisher, Ch. 19, Rijeka, 2011, pp. 403-430. 